Journal of Health Promotion and Behavior (2019), 4(1): 12-21

https://doi.org/10.26911/thejhpb.2019.04.01.02

\title{
Path Analysis on the Factors Affecting the Use of Personal Protection Equipment among Airport Construction Workers in Yogyakarta
}

\author{
Ristamaya Danar Dewi'), Setyo Sri Rahardjo²), Bhisma Murti1) \\ 1)Masters Program in Public Health, Universitas Sebelas Maret \\ 2)Faculty of Medicine, Universitas Sebelas Maret
}

\begin{abstract}
Background: Occupational accidents in the construction sector are still a major problem in every infrastructure development in Indonesia. The lack of supervision in the use of personal protective equipment (PPE) is one reason for the high number of occupational accidents. This study aimed to determine the factors that influence the implementation of the use of PPE.

Subjects and Method: A cross sectional study was conducted at Yogyakarta International Airport, Kulon Progo, Yogyakarta, Indonesia, in March 2019. A sample of 200 active field workers was selected by proportional random sampling. The dependent variable was the use of PPE. The independent variables were age, education, working experience, knowledge, perception of vulnerability, perceived benefit, perceived severity, and cues to action. The data were collected by questionnaire and analyzed by path analysis.

Results: The use of PPE was directly and positively affected by high knowledge $(b=2.14 ; 95 \% \mathrm{CI}=$ 1.17 to $3.10 ; p<0.001)$, high perceived susceptibility $(b=1.94 ; 95 \% \mathrm{CI}=0.95$ to $2.93 ; \mathrm{p}<0.001)$, high perceived severity $(\mathrm{b}=1.33 ; 95 \% \mathrm{CI}=0.42$ to $2.24 ; \mathrm{p}=0.004)$, high perceived benefit $(\mathrm{b}=1.79$; $95 \% \mathrm{CI}=0.85$ to $2.73 ; \mathrm{p}<0.001)$, and high cues to action $(\mathrm{b}=1.64 ; 95 \% \mathrm{CI}=0.67$ to $2.61 ; \mathrm{p}=0.001)$. The use of PPE was indirectly affected by age, work experience, and education.

Conclusion: The use of PPE is directly and positively affected by knowledge, perceived susceptibility, perceived severity, perceived benefit, and cues to action. The use of personal protective equipment is indirectly affected by age, work experience, and education.
\end{abstract}

Keywords: personal protective equipment, construction workers, path analysis

\section{Correspondence:}

Ristamaya Danar Dewi. Masters Program in Public Health, Universitas Sebelas Maret. Jl. Ir. Sutami 36A, Surakarta 57126, Central Java. Email: ristamayadd@gmail.com. Mobile: o82131666953 .

\section{BACKGROUND}

Hazards in the workplace are usually defined as working conditions that have the potential to cause injury and / or disease to workers. Examples of hazards are exposure to hazardous substances, working with dangerous tools and equipment, or carrying out potentially harmful tasks such as repetitive movements and heavy lifting (Yanaret al., 2018).

Based on data from BPJS Employment quoted by the Republic of Indonesia Health Office, the number of occupational accident cases in 2015 was 110,285 cases, while in 2016 there were 105,182 cases, which decreased by $4.6 \%$. Whereas until August 2017, there were 80,392 cases. Occupational accidents and work-related diseases not only cause material losses or fatalities and health problems for workers but can disrupt the production process as a whole and even damage the environment which ultimately affects the wider community. One of the causes of workplace accidents is the lack of optimal supervision and implementation of OSH and OSH behavior 
in the workplace. Therefore, it is necessary to make concrete efforts to prevent and reduce the occurrence of accidents and diseases due to work optimally (Ministry of Health, 2018).

The Director General of Manpower Inspection and Occupational Safety and Health, stated that the high number of occupational accidents was caused by a lack of maximum labor inspection due to a lack of labor inspectors. In 2018, the number of labor inspectors throughout Indonesia amounted to 2,676 active duty oversees 268,282 companies. Supervisors conducted a survey of 5 companies per month or around 6o companies per year (Ministry of Labor Republic of Indonesia, 2018).

The policy on occupational safety in Indonesia is regulated in Act No. 1 of 1970. The law imposes three elements, including the place where the work is carried out for a business, elements of labor, and elements of danger of work in the workplace. The dangers of the work environment are divided into chemical, physical, biological, physiological, and psychological hazards (Irzal, 2016).

Data of PT. PP (Persero) TBK in November 2018 recorded 1500 employees and will increase to 3000 to 3500 workers in January. The addition of employees is done to be able to pursue the target of completion of the planned runaway in 2019.

At the New Yogyakarta International Airport (NYIA) development project, the author found several workers who neglected to use primary PPE such as helmets, masks, and safety shoes. It can be influenced by various factors including age, work experience, knowledge, perceived susceptibility, perceived seriousness to use PPE, perceived benefit to use PPE, perceived barriers to use PPE, cues to action, self-efficacy, age, and tenure/ working experience.
This study aimed to determine the factors that influence the implementation of the use of personal protective equipment using health belief model (HBM) theory.

\section{SUBJECTS AND METHOD \\ a. Study Design \\ This was an analytic observational study with a cross sectional design. The study was conducted at the construction project of the New Yogyakarta International Airport, Ku- lon Progo, Yogyakarta, Indonesia, in March 2019.}

\section{b. Population and Samples}

The target population of this study was all field workers (5,472 workers) involved in the New Yogyakarta International Airport development project. A sample of 200 active field workers was selected by proportional random sampling.

\section{c. Study Variables}

The dependent variable was the use of PPE. The independent variables were age, knowledge, education, work experience, perceived susceptibility, perceived severity, perceived benefit, and cues of action.

\section{d. Operational Definition of Variables}

Age was defined the age of the workers based on birth date/ year of birth when the workers were interviewed. Age was measured by questionnaire and produced continous data.

Working experience was defined as the length of time or period of work that has been taken by the workers.

Knowledge was the result of "knowing". It happens after people have sensed a certain object. Sensing occurs through the human senses, namely: the senses of sight, hearing, feeling and touch.

Education was defined as the highest formal education attained by the workers.

Perceived susceptibility was defined as worker's perception about the risk of con- 
Journal of Health Promotion and Behavior (2019), 4(1): 12-21

https://doi.org/10.26911/thejhpb.2019.04.01.02

tracting the disease, or about how their behavior might affect their health.

Perceived severity was defined as worker's perception about the deleterious consequences of a serious health event or outcome.

Perceived benefit was defined as worker's motives to perform PPE use behavior. The measurement scale was continous.

Cues to action were defined as internal or external stimulus that influenced worker's desire to use PPE.

\section{e. Data Analysis}

Univariate analysis aimed to explain and describe the sample characteristics. Bivariate analysis was conducted to determine the relationship between the independent variables and the dependent variable using Chi square test. Multivariate analysis was conducted by path analysis run on Stata 13 .

\section{f. Research Ethics}

Research ethics in this study included anonymity, confidentiality, and informed consent. Research ethics approval was granted by the Research Ethics Committee at Dr. Moewardi hospital, Surakarta with number: 251/III/HREC/2019.

\section{RESULTS}

\section{Sample Characteristics}

Table 1 showed the sample characteristics. Table 1 showed that there were 124 workers (62\%) aged $<30$ years and 76 workers (38\%) aged $\geq 30$ years.

\section{Table 1. Sample characteristics (categorical data)}

\begin{tabular}{lcc}
\hline Characteristics & N & \% \\
\hline Age & 124 & 62 \\
$<30$ years & 76 & 38 \\
$\geq 30$ years & & \\
Education & 116 & 58 \\
$\quad<$ JHS & 84 & 42 \\
$\geq$ JHS & 118 & 59 \\
Working experience & 82 & 41 \\
<2 years & & \\
$>2$ years & 120 & 60 \\
Education & 80 & 40 \\
Poor & & \\
Good & 106 & 53 \\
Vulnerability perception & 94 & 47 \\
Low & & \\
High & 111 & 55.5 \\
Severity perception & 89 & 44.5 \\
Low & & \\
High & 103 & 51.5 \\
Benefit perception & 97 & 48.5 \\
Low & & \\
High & 102 & 51 \\
Cues to act & 98 & 49 \\
Low & & 75 \\
High & 150 & 25 \\
The use of PPE & 50 & \\
Incomplete PEE & & \\
Complete PEE & & \\
\hline
\end{tabular}


A total of 116 workers (58\%) with education $<$ junior high school and as many as 84 workers (42.0\%) with education $\geq$ Junior high school, the number of workers with $<2$ years work experience amounting to 118 people (59\%) and working experience $>2$ years amounting to 82 people (41\%). Workers with low benefit perceptions were 103 people (51\%) and workers with high perceptions of benefits were 97 people (48.5\%).

The number of workers with lowacting signals was 102 people (51\%) and 98 people (49\%) workers had a signal to act high. In the use of PPE as many as 150 workers (75\%) were incomplete and 50 workers (25\%) had used complete PPE.

\section{Bivariate Analysis}

Table 2 shows the results of bivariate analysis. Table 2 shows that age $>30$ years $(\mathrm{OR}=7.07$; $\mathrm{p}<0.001)$, education $\geq$ junior high school (OR= 8.27; $\mathrm{p}<0.001)$, working experience $>2$ years $(\mathrm{OR}=8.82 ; \mathrm{p}<0.001)$, high knowledge $(\mathrm{OR}=7.08 ; \mathrm{p}<0.001)$, high perceived susceptibility $(\mathrm{OR}=7.11 ; \mathrm{p}$ <0.001), high perceived severity (OR= 5.36; $\mathrm{p}<0.001)$, high perceived benefit $(\mathrm{OR}=3.75 ; \mathrm{p}<0.001)$, and high cues of action $(\mathrm{OR}=5.46 ; \mathrm{p}<0.001)$ increased the use of PPE.

\section{Table 2. Bivariate analysis}

\begin{tabular}{|c|c|c|c|c|c|c|c|c|}
\hline \multirow{3}{*}{ Independent Variables } & \multicolumn{4}{|c|}{ Use of PPE } & \multirow{2}{*}{\multicolumn{2}{|c|}{ Total }} & \multirow{3}{*}{$\mathbf{O R}$} & \multirow{3}{*}{$\mathbf{P}$} \\
\hline & \multicolumn{2}{|c|}{ Incomplete } & \multicolumn{2}{|c|}{ Complete } & & & & \\
\hline & $\mathbf{N}$ & $\%$ & $\mathbf{N}$ & $\%$ & $\mathbf{N}$ & \% & & \\
\hline \multicolumn{9}{|l|}{ Age } \\
\hline$<30$ years & 110 & 88.71 & 14 & 11.29 & 124 & 100 & \multirow[t]{3}{*}{7.07} & \multirow[t]{3}{*}{$<0.001$} \\
\hline$\geq 30$ years & 40 & 52.63 & 36 & $47 \cdot 37$ & 76 & 100 & & \\
\hline Education & & & & & & & & \\
\hline$<$ Junior high school & 105 & 90.52 & 11 & 9.48 & 116 & 100 & \multirow[t]{2}{*}{8.27} & \multirow[t]{2}{*}{$<0.001$} \\
\hline $\begin{array}{l}\geq \text { Junior high school } \\
\text { Working experience }\end{array}$ & 45 & $53 \cdot 57$ & 39 & 46.43 & 84 & 100 & & \\
\hline$<2$ years & 107 & 90.68 & 11 & 9.32 & 118 & 100 & \multirow[t]{2}{*}{8.82} & \multirow[t]{2}{*}{$<0.001$} \\
\hline $\begin{array}{l}>2 \text { years } \\
\text { Knowledge }\end{array}$ & 43 & 52.44 & 39 & $47 \cdot 56$ & 82 & 100 & & \\
\hline Lacking & 107 & 89.17 & 13 & 10.83 & 120 & 100 & \multirow[t]{3}{*}{7.08} & \multirow[t]{3}{*}{$<0.001$} \\
\hline Good & 43 & 53.75 & 37 & 46.25 & 80 & 100 & & \\
\hline Perceived susceptibility & & & & & & & & \\
\hline Low & 96 & 90.57 & 10 & 9.43 & 106 & 100 & \multirow[t]{3}{*}{7.11} & \multirow[t]{3}{*}{$<0.001$} \\
\hline High & 54 & 57.45 & 40 & 42.55 & 94 & 100 & & \\
\hline Perceived severity & & & & & & & & \\
\hline Low & 98 & 88.29 & 13 & 11.71 & 111 & 100 & \multirow[t]{3}{*}{$5 \cdot 36$} & \multirow[t]{3}{*}{$<0.001$} \\
\hline High & 52 & 58.43 & 37 & 41.57 & 89 & 100 & & \\
\hline Perceived benefit & & & & & & & & \\
\hline Low & 89 & 86.41 & 14 & 13.59 & 103 & 100 & \multirow[t]{3}{*}{3.75} & \multirow[t]{3}{*}{$<0.001$} \\
\hline High & 61 & 62.89 & 36 & 37.11 & 97 & 100 & & \\
\hline \multicolumn{7}{|l|}{ Cues to action } & & \\
\hline $\begin{array}{l}\text { Low } \\
\text { High }\end{array}$ & $\begin{array}{l}91 \\
59\end{array}$ & $\begin{array}{c}89.22 \\
60.2\end{array}$ & $\begin{array}{l}11 \\
39\end{array}$ & $\begin{array}{r}10.78 \\
39.8\end{array}$ & $\begin{array}{c}102 \\
98\end{array}$ & $\begin{array}{l}100 \\
100\end{array}$ & 5.46 & $<0.001$ \\
\hline
\end{tabular}

\section{Path Analysis}

\section{a. Model Specification}

This study consisted of 9 observed variables (age, education, work experience, knowledge, perceived susceptibility, perceived severity, perceived benefit, cues to action, and the use of PPE).

\section{b. Model Identification}

This stage would identify the number of measured variables, the number of endogenous variables, exogenous variables, and parameters to be estimated. At this stage, a degree of freedom (df) was calculated which indicated whether path analysis can be done 
Journal of Health Promotion and Behavior (2019), 4(1): 12-21

https://doi.org/10.26911/thejhpb.2019.04.01.02

or not as follows:

Measured variable $\quad: 9$

Endogenous variables $\quad: 7$

Exogenous variables $\quad: 2$

The degree of freedom formula was:

$\mathrm{df}=$ (number of measured variables $\mathrm{x}$ (number of measured variables +1 ) / 2(endogenous variables + exogenous variables + number of parameters)

$$
\begin{aligned}
& =(9 \times(9+1) / 2-(7+2+9)=(90 / 2)-18 \\
& =45-18=27
\end{aligned}
$$

Path analysis can be done if $\mathrm{df} \geq 0$, while in the identification of models in the over identified path analysis which mean that path analysis can be done. Figure 1 depicted the structural model of factors affecting the use of PPE.

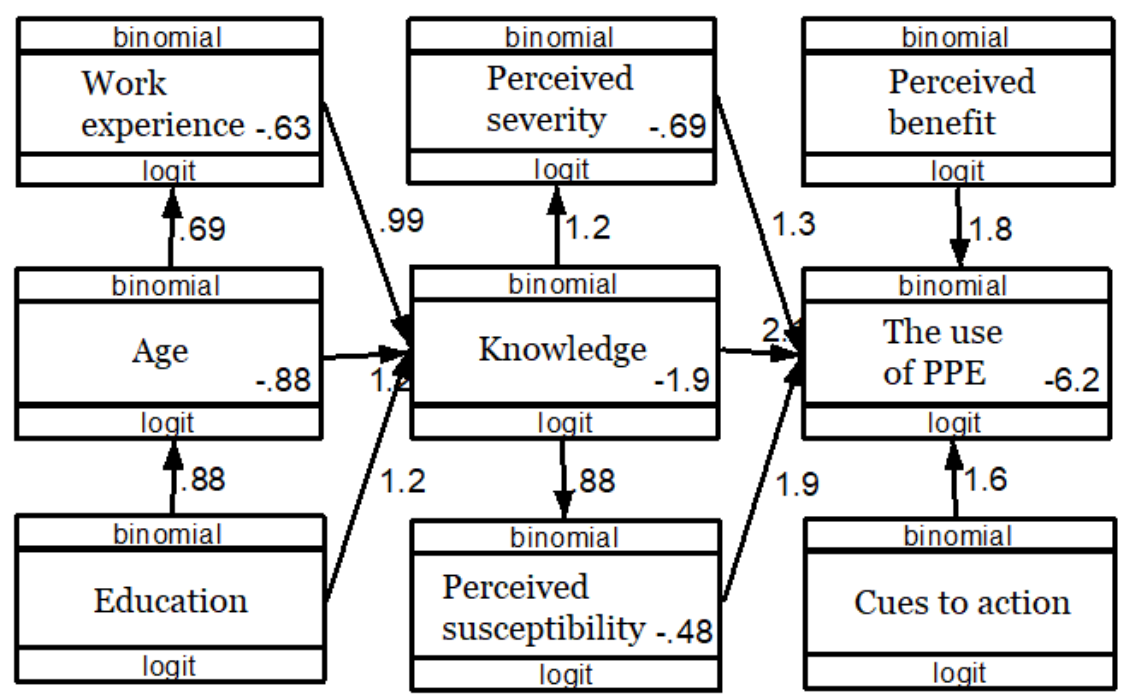

Figure 1. Structural model of factors affecting the use of PPE

Table 3 showed that the use of PPE was directly positively affected by knowledge, perceived susceptibility, perceived severity, perceived benefit, and cues to action.

Workers who have good knowledge have logodd to use PPE by 2.14 units higher than workers with less knowledge $(b=2.14$; 95\% $\mathrm{CI}=1.17$ to 3.10 ; $\mathrm{p}<0.001$ ).

Workers with high perceived susceptibility have logodd to use PPE by 1.94 units higher than those with low perceived susceptibility ( $b=1.94 ; 95 \% \mathrm{CI}=0.95$ to 2.93 ; $\mathrm{p}<0.001$ ).

Workers with high perceived severity have logodd to use PPE by 1.33 units higher than those with low perceived severity (1.33; $95 \% \mathrm{CI}=0.42$ to $2.24 ; \mathrm{p}=0.004$ ).

Workers with high perceived benefit have logodd to use PPE by 1.79 units higher than those with low perceived benefit $(b=$
1.79; $95 \% \mathrm{CI}=0.85$ to $2.73 ; \mathrm{p}<0.001)$.

Workers with high cues to action have a logodd to use PPE by 1.64 units higher than those with low cues to action $(b=1.64$; $95 \% \mathrm{CI}=0.67$ to $2.61 ; \mathrm{p}=0.001$ ).

The use of PPE was indirectly affected by work experience, age, and education.

Work experience was affected by age $(b=0.68 ; 95 \% \mathrm{CI}=0.10$ to $1.26 ; \mathrm{p}=0.021$ ). Knowledge was affected by age $(b=1.18$; 95\% $\mathrm{CI}=0.53$ to $1.83 ; \mathrm{p}<0.001)$, work experience $(b=0.99 ; 95 \% \mathrm{CI}=0.34$ to 1.63 ; $\mathrm{p}=0.003)$, and education $(\mathrm{b}=1.16 ; 95 \% \mathrm{CI}=$ 0.52 to $1.81 ; \mathrm{p}<0.001$ ).

Perceived susceptibility was affected by knowledge $(b=0.88 ; 95 \% \mathrm{CI}=0.30$ to 1.46; $\mathrm{p}=0.003$ ).

Perceived susceptibility was affected by knowledge $(b=1.15 ; 95 \% \mathrm{CI}=0.56$ to 1.73; $\mathrm{p}<0.001)$. 
Dewi et al./ Path Analysis on the Factors Affecting the Use of Personal Protection Equipment

Table 3. Path analysis on the factors affecting the use of PPE

\begin{tabular}{|c|c|c|c|c|c|c|}
\hline \multirow[b]{2}{*}{$\begin{array}{c}\text { Dependent } \\
\text { Variable }\end{array}$} & & \multirow[b]{2}{*}{ Independent Variable } & \multirow[b]{2}{*}{ (b) } & \multicolumn{2}{|c|}{ CI 95\% } & \multirow[b]{2}{*}{$\mathbf{p}$} \\
\hline & & & & $\begin{array}{l}\text { Lower } \\
\text { Limit }\end{array}$ & $\begin{array}{c}\text { Upper } \\
\text { Limit }\end{array}$ & \\
\hline \multicolumn{7}{|l|}{ Direct effect } \\
\hline \multirow[t]{5}{*}{ Complete PPE use } & $\leftarrow$ & Knowledge (good) & 2.14 & 1.17 & 3.10 & $<0.001$ \\
\hline & & Perceived susceptibility (high) & 1.94 & 0.95 & 2.93 & $<0.001$ \\
\hline & & Perceived severity (high) & 1.33 & 0.42 & 2.24 & 0.004 \\
\hline & & Perceived benefit (high) & 1.79 & 0.85 & 2.73 & $<0.001$ \\
\hline & & Cues to action (high) & 1.64 & 0.67 & 2.61 & 0.001 \\
\hline \multicolumn{7}{|l|}{ Indirect effect } \\
\hline Work experience & $\leftarrow$ & Age (>30 years old) & 0.68 & 0.10 & 1.26 & 0.021 \\
\hline \multirow[t]{3}{*}{ Knowledge } & $\leftarrow$ & Age (>30 years old) & 1.18 & 0.53 & 1.83 & $<0.001$ \\
\hline & & Work experience (>2 years) & 0.99 & 0.34 & 1.63 & 0.003 \\
\hline & & Education ( $\geq$ junior high school) & 1.16 & 0.52 & 1.81 & $<0.001$ \\
\hline \multirow{3}{*}{$\begin{array}{l}\text { Perceived } \\
\text { susceptibility } \\
\text { Perceived severity } \\
\text { Age }\end{array}$} & $\leftarrow$ & Knowledge (good) & 0.88 & 0.30 & 1.46 & 0.003 \\
\hline & $\leftarrow$ & Knowledge (good) & 1.15 & 0.56 & 1.73 & $<0.001$ \\
\hline & $\leftarrow$ & Education ( $\geq$ junior high school) & 0.88 & 0.29 & 1.46 & 0.003 \\
\hline \multicolumn{7}{|c|}{ N Observation $=\mathbf{2 0 0}$} \\
\hline \multicolumn{7}{|c|}{ Log likelihood $=-700.15$} \\
\hline \multicolumn{7}{|c|}{$\mathrm{AIC}=1436.3$} \\
\hline \multicolumn{7}{|l|}{$\mathrm{BIC}=1495.7$} \\
\hline
\end{tabular}

\section{DISCUSSION \\ 1. The effect of knowledge on the use of PPE}

The results of this study indicated that knowledge has a direct and positive effect on the use of PPE and the effect was statistically significant. Knowledge of workers influenced the implementation of the use of PPE. Less knowledge was caused by lack of experience of workers in the construction sector.

Anizar (2014) stated that knowledge can give confidence to someone to determine the attitude to act. The results of the study by Hussain et al. (2019) showed that lack of knowledge on workers can reduce the use of PPE. Piai-Morais et al. (2015) reported that knowledge has a major influence on compliance in using PPE $(b=4.69)$. Based on the description above, the author concluded that workers with good knowledge would use PPE properly compared to workers with insufficient knowledge so that the implementation of the use of PPE was low.

\section{The effect of perceived susceptibi- lity on the use of PPE}

The results of this study indicate that there was a direct and positive influence of perceived susceptibility with the use of PPE. Worker's perceived susceptibility affected the use of PPE. Low perceived susceptibility was caused by a lack of workers' knowledge of the disease, the dangers of work, and the importance of PPE use. So they did not feel that they were vulnerable to work-related illnesses and ignore the importance of using PPE.

Setyaningsih et al. (2017) showed that there was an influence of perceived susceptibility. The study reported that high perceived susceptibility increased the use of PPE by 0.39 times higher $(b=0.39$; $\mathrm{p}<0.001)$. Herrmann et al. (2018), also stated that perceived susceptibility effected on health-related preventive behavior.

This was in accordance with Health Belief Model theory that developed by Rosenstock (1994) that the assumption that an individual was affected by an illness would 
Journal of Health Promotion and Behavior (2019), 4(1): 12-21

https://doi.org/10.26911/thejhpb.2019.04.01.02

make themselves aware of a prevention and protection (Murti, 2018).

Based on the results of this study, it can conclude that workers who have a high perceived vulnerability to occupational diseases and occupational hazards, would make efforts to prevent the occurrence of occupational diseases and occupational hazards by using PPE.

\section{The effect of perceived severity on the use of PPE}

The results of this study indicated that there was a direct and positive effect of perceived severity on the use of PPE.

Wulandari et al. (2016), stated that there was a positive effect between perceived severity and preventive behavior $(\mathrm{p}=$ 0.031). Gholampouretal (2018), stated that individuals with high perceived severity increased prevention behavior compared to individuals with low perceived severity.

Based on the description above, the writer can conclude that workers who have high perceived severity would make the worker willing to use PPE to prevent workrelated illness. This was because they did not want to get serious illness so they would make an effort to prevent the occurrence of disease.

\section{The Effect of Perceived Benefit on the Use of PPE}

The results of this study indicated that there was a direct and positive effect of perceived benefits on the implementation of the use of PPE and it was statistically significant.

The results of this study were in line with Obirikorang et al. (2018) which stated that high perceived benefits of using drugs were significantly correlated with the reduced chance of non-compliance of the study subject to an action.

The reduction in the non-compliance rate of the subject of this study was based on evaluation using the health belief model method that was not used in the previous evaluation. This study was in line with Støle et al. (2019) who stated that there was a relationship of perceived benefit on an action and it became one of the variables in this study with the highest correlation with behavior in both bivariate and multivariate analysis.

Based on the description above, the writer can conclude that individuals who have a high perceived benefit of using PPE, then the individual would make an effort to prevent work accidents and prevention of occupational hazards by using PPE.

\section{The Effect of Cues to Action on the Use of PPE}

This study indicated that there was a direct and positive influence of high cues to action on the implementation of the use of PPE and it was statistically significant.

This study was in line with that of Puspita et al. (2009) which proved that cues to action influenced behavior in preventive behavior. The Patterson et al. (2018) study stated that the cues to action can increase prevention efforts.

Based on the description above, the writer can conclude that individuals who have high cues to action on the use of PPE, then the individual would make an effort to prevent work accidents and prevent work hazards by using PPE.

\section{The Effect of Age on the Use of PPE}

The results of this study indicated that there was an indirect and positive influence between the age and the use of PPE through knowledge and experience and it was statistically significant. Workers who were $\geq 30$ years old have the possibility to use a PPE greater.

The results of this study were also in line with the study of Holte KA. and Kjestveit (2012) who explained that construction workers aged $<30$ years old were more likely to experience work accidents due to negligence in the use of PPE. How- 
ever, the results of this study were not in line to the study of Abdollahzadeh and Damalas (2016), which stated that older age has a significant negative influence on the use of PPE.

Based on the description above, the writer can conclude that workers aged $\geq 30$ years old have better knowledge of occupational hazards and work-related diseases, so these workers would make efforts to prevent occupational hazards and work-related diseases, using PPE.

\section{The Effect of Experience on the Use of PPE}

The results of this study indicated that there was an indirect and positive effect of experience on the use of PPE through knowledge and it was statistically significant. Workers who have $>2$ years of work experience have the possibility to use PPE more.

The results of this study were in line with Low et al. (2018) which proved that changes in attitudes and perceptions of construction workers were influenced by previous experience. This statement was reinforced by a study from Navarro et al. (2018) which stated that groups of study subjects with work experience of 2-5 years would show a higher level of achievement compared to groups of study subjects who have work experience $<2$ years.

Based on the description above, the writer can conclude that workers who have work experience or a longer working period (>2 years) have better knowledge about occupational hazards and work-related diseases, so that these workers would make efforts to prevent occupational hazards and occupational diseases, using PPE.

\section{The Effect of Education on the Use of PPE}

The results of this study indicated that there was an indirect and positive effect of education on the use of PPE through knowledge and age and it was statistically significant.
Employees who were $\geq$ JHS have the possibility to use PPE higher. This study was in line with Khodaminasab et al. (2019) which stated that the results of the study showed that self-care behavior waas significantly related to educational level $(\mathrm{p}=0.003)$. Participants who were employed and have higher education showed better self-care behavior than others. Uchmanowicz et al. (2018), stated that education levels significantly influenced action.

Based on the description above, the writer can conclude that workers who were junior high school graduate or above have better knowledge of occupational hazards and occupational diseases. Therefore, these workers would make an effort to prevent occupational hazards and work-related diseases. One of the effeort was by using PPE.

\footnotetext{
AUTHOR CONTRIBUTION

Ristamaya Danar Dewi collected data and wrote the paper. Setyo Sri Rahardjo examined the conceptual framework and study method. Bhisma Murti ran statistical analysis and interpreted the results of analysis.
}

\section{FUNDING AND SPONSORSHIP}

This study used the authors' independent costs.

\section{ACKNOWLEDGEMENT}

We would like to express our gratitude to PT. PP (Persero) which has given permission for data collection and the workers who were willing to be study subject.

\section{CONFLICT OF INTEREST}

There was no conflict of interest.

\section{REFERENCE}

Abdollahzadeh G, Damalas C (2016). Farmers use of personal protective equipment during handling of plant pro- 
Journal of Health Promotion and Behavior (2019), 4(1): 12-21

https://doi.org/10.26911/thejhpb.2019.04.01.02

tection products: Determinants of implementation. Science of the Total Environment. 571:730-736. https://doi.org/10.1016/j.scitotenv.2016.07.042.

Anizar A (2014).Teknik keselamatan dan kesehatan kerja industri. Yogyakarta: Graha Ilmu.

Gholampour Y, Jaderipour A, Jeihooni AK, Kashfi SM, Harsini PA (2018). The effect of educational intervention based on health belief model and social support on the rate of participation of individuals in performing fecal occult blood test for colorectal cancer screening. Asian Pacific Journal of Cancer Prevention. 19: 27772787.doi:10.22034/APJCP.2018.19.10 .2777 .

Herrmann A, Hall A, Proietto A (2018). Using the Health Belief Model to explore why women decide for or against the removal of their ovaries to reduce their risk of developing cancer. BMC Women's Health. 18:1-14. https://doi.org/10.1186/s12905-0180673-2.

Holte KA, Kjestveit K (2012). Young workers in the construction industry and initial OSH-training when entering work life, department of social science and business development. International Research Institute of Stavanger. 41: 4137-4141. doi: 10.3233/WOR-2012-0709-4137.

Hussain N, Kadir MM, Nafees AA, Karmaliani R, Jamali T (2019). Figure-1: Conceptual framework of needs assessment for health and safety intervention in textile industry (adapted from framework of World Health Organisation for evaluating a health promotion programme). Journal of Pakistan Medical Association. 69(1): 87-93. Available at: http://jpma.-
org.pk/PdfDownload/9006.pdf.

Kemenkes RI (2018).Peringatan Bulan $\mathrm{K}_{3}$ Nasional 2018. Jakarta: Kementrian Kesehatan Republik Indonesia. Available at: www.Depkes.go.id .

Kementrian ketenagakerjaan (2018). Penguji K3 dan Pengawas Ketenagakerjaan Tingkatkan Sinergi Cegah Kecelakaan Kerja. Jakarta. Available at: www.kemnaker.go.id.

Khodaminasab A, Reisi M, Vahedparast H, Tahmasebi R, Javadzade H (2019). Utilizing a health-promotion model to predict self-care adherence in patients undergoing coronary angioplasty in Bushehr, Iran, Patient Preference and Adherence. Dove Press Journal 13: 409-417. doi: 10.2147/ppa.s181755.

Low BK, Man SS,Chan AH (2018). The risktaking propensity of construction workers-An application of Quasiexpert interview.International Journal of Environmental Research and Public Health, 15(10). doi: 10.3390/ijerph15102250.

Murti B (2018). Teori Promosi dan Perilaku Kesehatan. Karanganyar: Bintang Fajar Offset.

Navarro AY, Torre LC, Salgado JG, Rodríguez JA (2018). Job satisfaction and perceived health in Spanish construction workers during the economic crisis.International Journal of Environmental Research and Public Health, 15(10). doi: 10.3390/ijerph15102188.

Obirikorang Y, Obirikorang C, Acheampong E, Anto EO, Gyamfi D, Segbefia SP, Boateng MO, Dapilla DP, Brenya PK, Amankwaa B, Adu EA, Batu EN, Akwasi AG, Amoah B (2018). Predictors of Noncompliance to antihypertensive therapy among hypertensive patients Ghana: Application of Health Belief Model.International Journal of 
Hypertension. Hindawi, 2018:1-9. doi: 10.1155/2018/4701097.

Patterson NM, Bates BR, Chadwick AE, Sanchez CN, Mario J (2018). Using the health belief model to identify communication opportunities to prevent Chagas disease in Southern Ecuador. Journal of Plos Neglected Tropical Diseases. 1-14. https://doi.org/10.1371/journal.pntd.ooo6841

Piai-Morais TH, Orlandi FS, Figueiredo RM (2015) Factors influencing adherence to standard precautions among nursing professionals in psychiatric hospitals, Revista da Escola de Enfermagem. Journal of School of Nursing Revista Da Escola De Enfermagem Da USP. 49(3):473-480. doi: 10.1590/Soo8o-623420150000300016.

Puspita RC, Tamtomo D, Indarto D (2009). Health belief model for the analysis of factors affecting hypertension preventive behavior among Adolescents in Surakarta. Journal of Health Promotion and Behavior.2(2): 183-196. Https://doi.org/thejhpb.2016.02.02.0 81172.

Setyaningsih R, Tamtomo D, Suryani N (2017). Health belief model: Determinants of hypertension prevention behavior in adults at community health center, Sukoharjo, Central Ja- va. Journal of Health Promotion and Behavior. 01(03): 160-170. doi: 10.26911/thejhpb.2016.01.03.03.

Støle HS, Nilsen LT, Joranger P (2019) Beliefs, attitudes and perceptions to sun-tanning behaviour in the Norwegian population: a cross-sectional study using the health belief model. BMC Public Health. 19: 1-12 https://doi.org/10.1186/s12889-019-6503-0.

Uchmanowicz B, Chudiak A, Uchmanowicz I, Rosińczuk J, Froelicher ES (2018). Factors influencing adherence to treatment in older adults with hypertension, Clinical Interventions in Aging. Dove Press Journal. 13:24252441. doi: 10.2147/CIA.S182881.

Wulandari YA, Suryani N, Poncorini E (2016). Health Belief Model: Health preventive behavior of sexually transmitted infection in female sex workers in Surakarta. Journal of Health Promotion and Behavior 1(2):70-78. https://doi.org/10.26911/thejhpb.201 6.01.02.02.

Yanar B, Kosny A (2018). Occupational health and safety vulnerability of recent immigrants and refugee, international. Journal of Environment and Public Health. 15(9): 2004 doi: 10.3390/ijerph15092004. 